\title{
THE LAPIDARY COLLECTION OF THE TAMAN ANCIENT SETTLEMENT: IDENTIFICATION OPTIONS OF THE BYZANTINE RELIEFS
}

\author{
Ekaterina Yu. Endoltseva \\ Institute of Oriental Studies, Russian Academy of Sciences, Moscow, Russian Federation \\ Viktor N. Chkhaidze \\ Institute of Archaeology, Russian Academy of Sciences, Moscow, Russian Federation
}

\begin{abstract}
The paper presents heterogeneous carved stone blocks of the Middle Ages, originating from different parts of the Taman settlement. Some of them are preserved only in photos, the rest are kept in the collection of the Taman archaeological Museum, as well as in Krasnodar. The considered artifacts are divided into three groups: 1) columns' capitals and their fragments; 2) fragment of the plate depicting an angel holding the scarf; 3) blocks decorated with "twist"-type ornaments. Byzantine reliefs belong to two chronological groups. The first group (end of the 5th-6th c.) unites the four capitals and the fragment of plate with angel. Their presence proves the hypothesis that a church building of the early Byzantine period was located somewhere on the Taman settlement. The second group (9th-11th c.) includes the lost reliefs that were registered in the photos of the archaeological records by A.S. Bashkirov and B.A. Rybakov. It is likely that they are connected with the Byzantine church of the inscribed-cross type on the four pillars or columns, built in the 10th-11th centuries and existed in the Taman settlement till the 18th century. Analogies and the date of construction of the church allow narrowing down the period, shifting the emphasis in favor of the 11th century.

Key words: Taman settlement, capitals, columns, reliefs, Christianity, Church, Middle Ages, Byzantium.
\end{abstract}

\section{ЛАПИДАРНАЯ КОЛЛЕКЦИЯ ТАМАНСКОГО ГОРОДИЩА: ВАРИАНТЫ ИДЕНТИФИКАЦИИ ВИЗАНТИЙСКИХ РЕЛЬЕФОВ ${ }^{1}$}

\author{
Екатерина Юрьевна Ендольцева \\ Институт востоковедения РАН, г. Москва, Российская Федерация \\ Виктор Николаевич Чхаидзе


Ключевые слова: Таманское городище, капители, колонны, рельефы, христианство, храм, Средние века, Византия.

В ходе археологических и натурных исследований разных лет на Таманском городище и в его окрестностях были обнаружены разнородные резные каменные блоки эпохи Средневековья. Судя по имеющимся сведениям, они происходят из разных частей станицы Тамани. Информация о части из них сохранилась только благодаря черно-белым фотографиям, остальные - находятся в коллекции Таманского филиала Краснодарского историко-археологического музея ${ }^{2}$.

Рассматриваемые артефакты можно разделить на три группы: 1) капители колонн и их фрагменты; 2) фрагмент плиты с изображением ангела, держащего плат; 3) ныне исчезнувшие блоки, украшенные орнаментом типа «плетенка», запечатленные на черно-белых фотографиях. Детальное исследование этой коллекции, результатом которого стала бы научная публикация всех ее артефактов, до сих пор не проводилось.

Некоторые из рельефов (две капители колонн и плита с ангелом) вскользь упоминаются при описании раннехристианских древностей раннесредневековой Гермонассы - Таматархи в контексте реконструкции ее истории [6, с. 93-95, рис. 48-49]. В еще одной работе, посвященной истории и архитектурным особенностям средневекового храма на Таманском городище [14], упоминаются колонны, хранившиеся в 20-50-х гг. ХХ в. в звоннице церкви Покрова Пресвятой Богородицы в Тамани (построена в 1911 г. на месте старой, возведенной в XVIII веке). Эти сведения известны благодаря работе А.С. Башкирова [3, с. 158, рис. 54]. В статье М. Тихановой-Клименко приведены две капители, выступающие в качестве аналогий при исследовании капителей-сполий, украшающих интерьер церкви Св. Иоанна Крестителя в Керчи [24, p. 9, fig. 8 9]. Цель настоящего исследования - ввести в научный оборот все происходящие из Тамани средневековые резные каменные блоки и обосновать возможности их датировки. Для реализации задуманного рельефы будут рассматриваться в соответствии с обозначенными выше группами.
Резные камни первой группы однородны с точки зрения использованного при их производстве материала. Это крупнозернистый мрамор с характерными серо-голубоватыми полосами. Фактура породы позволяет предположить, что происходит она из хорошо известных мрамороломен на о. Проконнес в Пропонтиде (ныне о. Мармара в Мраморном море). Подробная библиография исследований последних десятилетий, касающихся распространения и производства раннесредневекового византийского мрамора, изложена в книге Л.Г. Хрушковой, посвященной раннехристианским памятникам Восточного Причерноморья [13, с. 355-359].

Фрагмент капители (см. рис. 1,1$)$, выставленный в экспозиции Таманского археологического музея (инв. КМ-6094/40/ТАМ-404) ${ }^{3}$, был найден на ул. Декабристов в 1976 году. Его размеры: 45 см по верхнему диаметру, 40 см - по нижнему, высота - 28 см. Сохранившаяся резьба помогает идентифицировать фрагменты листьев аканфа, расположенных в два яруса. Они мягко отогнуты, образуя в нижнем ярусе на стыке листьев стилизованные геометрические фигуры, круги и ромбы небольшого размера. Из описания следует, что рассматриваемая капитель относится к коринфскому ордеру. По мнению А.Л. Якобсона, такой тип коринфской капители с мягким римским аканфом получил широкое распространение по всему Средиземноморью [17, с. 135]. Он был выработан в мастерских Проконнеса еще в V веке. В VI в. производство таких капителей было массовым. «Нижний ярус состоит из пяти широких листьев со слабым отгибом верхней части; лопасти расположены симметрично друг к другу, встречаясь концами и образуя фигурные промежутки в виде ромбиков и кружков. Верхний ярус состоит из четырех веток аканфа, помещенных соответственно по углам абака; листья ложатся на смежные стороны капители. Венчает капитель плоский квадратный абак со впалыми сторонами» [17, с. 136]. Такого рода капители с относительно низким рельефом резьбы и с почти исчезнувшим отгибом листьев, больше нарисованном в мраморе, чем высечен- 
ном, встречаются повсеместно и, бесспорно, относятся к VI веку. Среди территориально близких аналогий следует прежде всего указать на группы капителей из Херсонеса [18, nr 731/973, s. 319, tab. 47; nr 768/973, s. 326, tab. 47; nr 767/973, s. 326, tab. 48; nr 192/973, s. 205 , tab. 51; nr 8/973, s. 168 , tab. 53; nr 594/ 973, s. 292, tab. 55; nr 536/973, s. 276, tab. 55; nr 56/973, s. 177, tab. 56; nr 552/973, s. 280, tab. 57; nr 50/973, s. 175, tab. 59] и из церкви св. Иоанна Крестителя в Керчи [24, по 2, р. 6 , fig. 3]. Среди наиболее известных образцов капителей такого рода, например, капители колоннады среднего нефа базилики Аполлинария Нового в Равенне (VI в.). В целом они получили широкое распространение в византийском искусстве этого времени $[17$, с. 138 , сноска 1]. К этому же типу капители относится, вероятно, и другой небольшой фрагмент (рис. 1, 2) (инв. КМ-6094/38/ТАМ-402). Его размеры: $32 \times 21$ см, глубина рельефа около 2 см.

Вторая капитель (рис. 1, 3-5) «с квадратным углублением внизу» установлена на неродной ей колонне во внутреннем дворике музея (инв. КМ-4770/ТАМ-181). Капитель была найдена на углу ул. Лебедева и ул. Оболенского. Ее размеры: верхний диаметр 39 см, нижний диаметр - 33 см, высота 40 см. Капитель достаточно хорошо сохранилась, если не считать небольшие утраты в верхнем ярусе резьбы. Ее упоминание содержится в статье П.В. Новикова [9, с. 156, рис. 67]. Эту капитель, как и предыдущую, вероятно, также можно датировать VI в., так как в этот период в мастерских Проконнеса «была выработана специального назначения капитель, стилистически примыкающая к той же коринфско-византийской капители с листвой
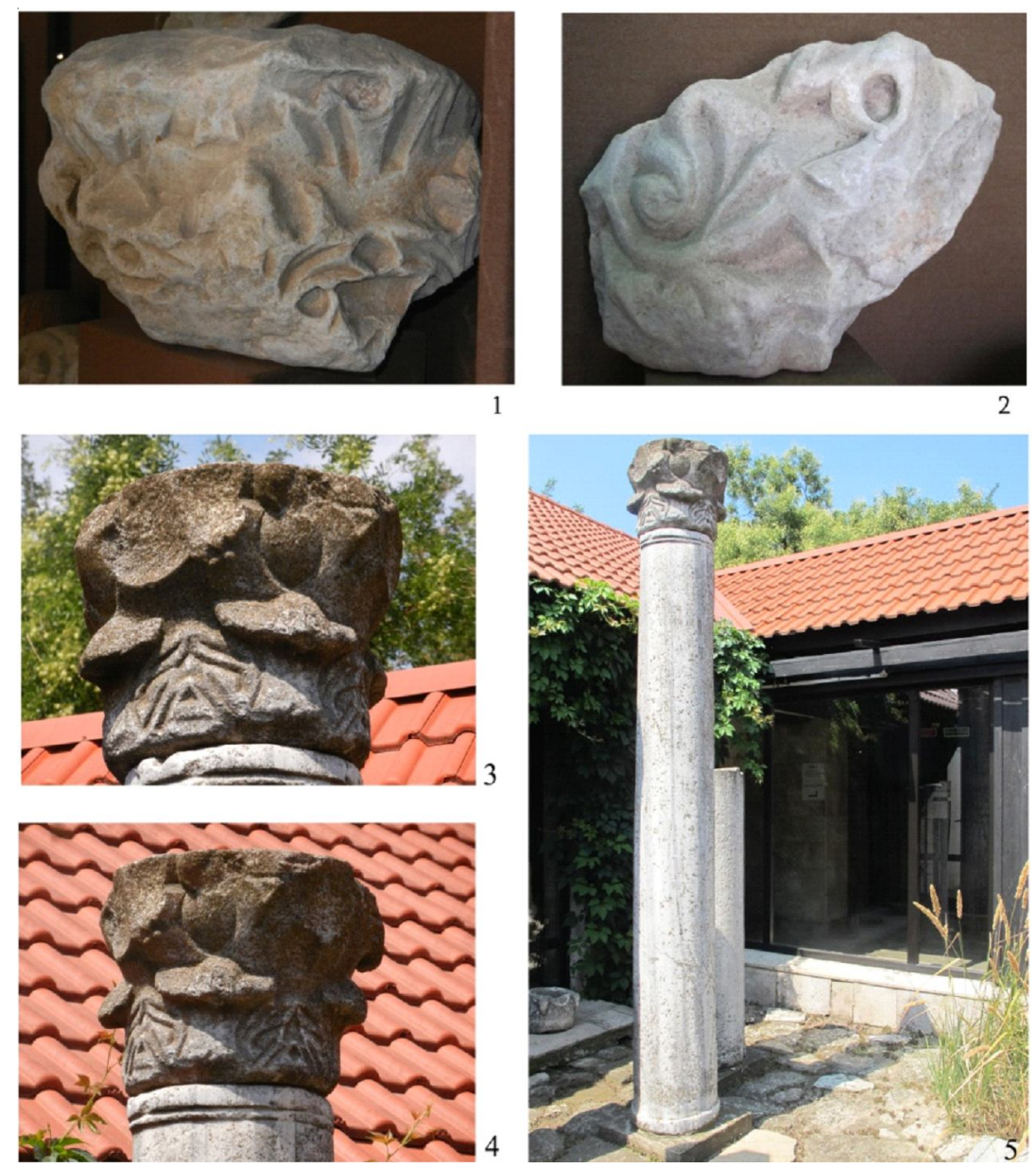

Рис. 1. Капители из Таманского музейного комплекса:

1 - капитель КМ-6094/40/ТАМ-404. 1976 г.; 2 - фрагмент капители КМ-6094/38/ТАМ-402; 3-5 - капитель КМ-4770/ТАМ-181

Fig. 1. Capitals from the Taman Museum Complex 
мягкого аканфа в ее поздней редакции, но в сильно упрощенном и схематизированном виде» [17, с. 138]. Аканфовый лист практически утратил рельеф и трактован совершенно условно. Круглые и ромбовидные впадинки лишь намекают на завитки и контуры листьев. Среди ближайших аналогий, как и в случае с первой капителью, - капители из Херсонеса [18, nr 191/973, s. 205, tab. 52] и Керчи [24, no 3, p. 7, fig. 4]. Такие капители встречаются и в юго-восточной части Черноморского побережья Кавказа (Грузия, Зугдидский район). Так, к этому же типу, судя по всему, относятся две коринфские капители из церкви в Цаиши: как отмечает Л.Г. Хрушкова, «таких капителей много во второй половине $\mathrm{V}$ в., они встречаются до юстиниановской эпохи. Всего их известно свыше 150 экз. Около 30 экземпляров подобных капителей было найдено в Херсонесе, где они датированы VI в., немало аналогий происходит из Болгарии, Румынии, Константинополя, Эфеса, Греции, Кипра и других мест» [13, с. 365].

Еще одна подобная вышеописанной капители из Тамани находится в Краснодаре (лапидарий КГИАМЗ им. Е.Д. Фелицына). Ее размеры: высота - 37 см, диаметр - 36 см [9, с. 153-156, рис. 9].

Вариантом вышеописанного типа коринфско-византийской капители может считаться и третья капитель (см. рис. 2, 1-2), поступившая в музей в числе находок, обнаруженных еще до Великой Отечественной войны. Ее размеры: верхний диаметр - 45 см, нижний -30 см, высота - 38 см. Глубина рельефа - 1,5 см. Здесь среди листьев аканфа верхнего ряда видны фрагменты крестов с расширяющимися к концам перекладинами. Как и в предыдущих случаях, ближайшие аналогии этому артефакту встречаются среди переиспользованных капителей из церкви в Керчи [ 24 , no 1 , p. 5 , fig. 2 ; no 4 , p. 8 , fig. 5] и среди капителей Херсонеса [18, nr 15/973, s. 169, tab. 51; nr 16/973, s. 169, tab. 97]. Этот тип капителей распространен и в других регионах византийского мира включая Константинополь (к примеру, капитель из цистерны около Фетхие-Джами) [24, p. 16, fig. 12]. Стилистические особенности резьбы также позволяют отнести эту группу капителей к VI в. [4, с. 99; 23, p. 21-22].
Четвертая капитель (см. рис. 2, 3) того же подтипа, что и третья. Она также относится к находкам, поступившим в музей еще до Великой Отечественной войны. Ее размеры: верхний диаметр - 44 см, нижний диаметр - 33 см, высота - 37 см, глубина рельефа $-1,5$ см. Однако в ней есть одна необычная деталь. Крест, изображенный между раздвинутыми листьями аканфа, сплетен из двух лент плетения в одну полосу. Аналогии креста, сплетенного таким образом, в ранневизантийском искусстве нам неизвестны [22]. В более позднее время плетеные кресты встречаются в архитектурной пластике Византии и Кавказа. Однако они обычно составлены из петелек и кружков большего и меньшего радиуса лентой плетения в две или три полосы (см.: [20, pl. XLV, 3]). Как правило, этот элемент орнамента датируется временем не раньше X века. Правда, в некоторых случаях, например, на фрагментах балюстрады интерколумниев из Херсонеса, встречается изображение хризмы, обрамленной вьющейся лентойлианой $[18, \mathrm{nr} 759 / 973$, s. 324-325, tab. 142; nr 356/973, s. 239, tab. 143; nr 372/973, s. 243, tab. 144; nr 334/973, s. 234-235, tab. 146; nr 691/973, s. 312 , tab. 148; nr 724/973, s. 318, tab. 148 и др.]. Все эти фрагменты датируются VI веком. Возможно, плетеный крест на четвертой капители из Тамани демонстрирует развитие этого художественного приема. В любом случае, стилистические особенности резьбы окружающего его аканфа позволяют, как кажется, сопоставить эту капитель с предыдущей. В этом случае датировка VI в. представляется правдоподобной. К этому же периоду можно отнести и еще один фрагмент капители (см. рис. 2, 4) тоже из мрамора (инв. КМ-4770/ТАМ-262). Его размеры: длина $-12,5$ см, ширина -9 см, толщина $-5,3$ см, глубина рельефа $-1,5$ см.

Ко второй группе рельефов относится выставленный в экспозиции Таманского музея фрагмент плиты с изображением ангела (см. рис. 2, 5) (инв. КМ-4770/ТАМ-74), найденный в районе старой Таманской школы № 2. Размеры фрагмента - 39,5 × 24,5×8 см. На сохранившейся части плиты представлена верхняя часть туловища ангела с нимбом и двумя крыльями. Его фигура показана в профиль, голова повернута в три четверти к зрителю. Высокий лоб с прямым пробором и 

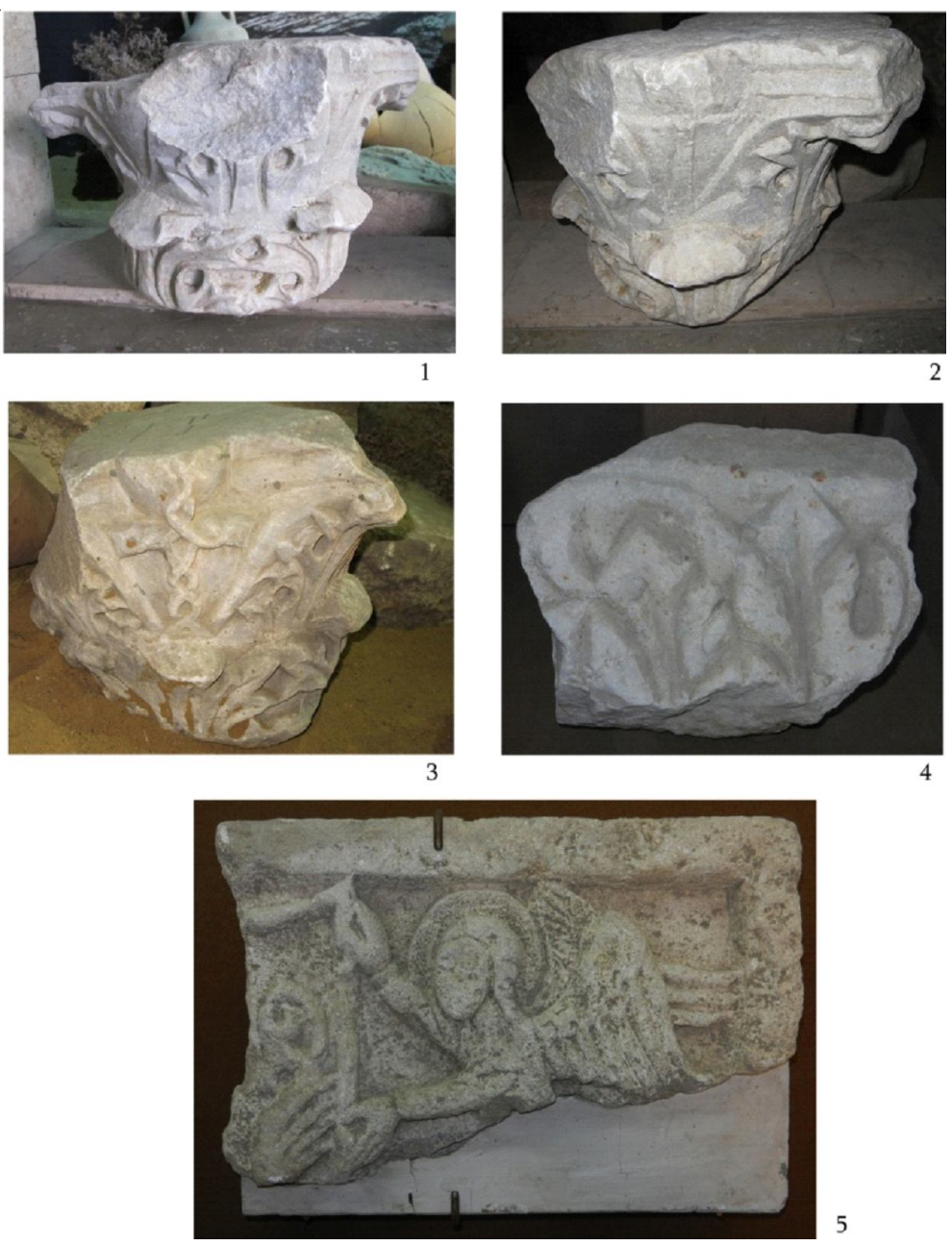

Рис. 2. Капители и плита с изображением ангела из Таманского музейного комплекса:

1-2 - капитель б/№. До 1941 г;; 3 - капитель б/№. До 1941 г.; 4 - фрагмент капители КМ-4770/ТАМ-262; 5 - плита с изображением ангела КМ-4770/ТАМ-74

Fig. 2. Capitals and the plate depicting an angel from the Taman Museum Complex

спускающиеся до плеч локоны выполнены короткими экспрессивными насечками. Двумя руками с увеличенными кистями ангел держит, вероятно, плат. Его уцелевший край обозначен сильно выступающим валиком. Черты лица ангела сохранились плохо, видны только глаза, слегка намеченные насечками круглой формы. Крылья показаны в динамичной манере, каждое перо обозначено параллельными глубокими насечками.

Реконструируемая по фрагменту сцена относится к числу широко распространенных в христианском искусстве начиная c IV века. К примеру, на стенке детского саркофага из Археологического музея Стамбула (IV в.) показаны два ангела, поддерживающие хризму [20, pl. VII, 1-3]. Изображение выполнено удивительно пластично подобно лучшим образцам античной скульптуры. Этот же сюжет встречается, к примеру, на предметах из слоновой кости, относящихся к разным периодам византийского средневекового искусства. На консульском диптихе из Лувра (VI в.) [25, Nr. 48, Taf. 12] два ангела изображены поддерживающими погрудное изображение Христа в мандорле. Данная иконография типологически связана с античными изображениями крылатых Викторий, поддерживающих погрудное изображение императора-триумфатора или консула в лавровом венке. Такие изображения продолжают существовать и в христианское время (Консульский диптих из Милана, VI в.) [25, Nr. 49, Taf. 12]. Они могут появляться на предметах повседневной необ- 


\section{ИСТОРИЯ, КУЛЬТУРА, ПРАВО В ВИЗАНТИЙСКИХ ПРОВИНЦИЯХ}

ходимости (костяной гребень из Каира, на котором ангелы поддерживают изображение молящегося всадника в медальоне, VI в.) [25, Nr. 204, Taf. 59]. Ангелы, поддерживающие крест в лавровом венке, традиционно украшали оклады евангелий и диптихи VI-IX вв.: диптих из Равенны, VI в. [25, Nr. 125, Taf. 39], оклад Евангелия из Эчмиадзина, VI в. [25, Nr. 142, Taf. 44], оклад Евангелия св. Луписина из Парижа, VI в. [25, Nr. 145, Taf. 47], оклад Евангелия из Ватикана, IX в. [25, Nr. 223, Taf. 62]. В такой ситуации основной стратегией для выработки гипотезы датировки артефакта может служить анализ технических и стилистических особенностей изображения. Так, несколько грубоватая манера, в которой исполнен лик ангела, неправильный овал его головы и прическа (волосы до плеч с кудрями, показанными короткими горизонтальными насечками), а также материал (известняк) сближают фрагмент плиты из Тамани с фрагментом плиты из Археологического музея в Стамбуле с изображением безбородого человека (возможно, Христос) [20, pl. XIV, 2]. В похожей манере изображен ангел на композитной капители из того же музея в Стамбуле [20, pl. XIX, 4-5]. Рассуждая о вариантах датировки рельефа с Христом из Стамбула, А. Грабар отмечает грубую манеру его исполнения, однако в результате сопоставления с некоторыми другими рельефами, а также анализа технических особенностей резьбы (проработки складок одежды, локонов волос и т. д.) относит изображение к V в. [20, p. 50-52]. Что касается капители с ангелом, то А. Грабар видит в ней «пример капителей, распространенных в Византии в конце V - начале VI в.» [20, p. 65]. Таким образом, кажется возможным согласиться с мнением А.К. Коровиной, которая, ссылаясь на предположение А.В. Банк, относит этот рельеф к V-VI вв. [6, с. 93]. В изображении плата, который держит ангел, есть, правда, одна непонятная деталь. Сохранность рельефа не позволяет идентифицировать вырезанный на нем образ. Судя по имеющемуся фрагменту здесь представлена нижняя часть растения с пышной листвой у корня и извилистым стеблем, либо фрагмент крыла неизвестного существа, либо часть руки. Как уже было сказано, на настоящем уровне исследования проблемы идентифицировать это изображение не представляется возможным за неимением прямых иконографических аналогий. Вероятно, если когда-либо удастся определить представленный сюжет, то и датировка плиты может быть уточнена.

К последней, третьей группе, относятся исчезнувшие рельефы, известные только по черно-белым фотографиям из публикаций и отчетов А.С. Башкирова [1, с. 39, рис. 2; 2, рис. 52-57; 3, с. 158-163, рис. 55-60] (см. рис. 3, $1-3)$ и из отчетов 1953-1954 гг. Таманской экспедиции Института археологии АН СССР под руководством Б.А. Рыбакова [11, рис. 147-149, $151 ; 12$, рис. $62-63,65]$ (см. рис. 4, $a-ж$ ).

В ходе осмотра древностей Тамани в 1926 г. и в 1948 г. А.С. Башкиров обнаружил и зафиксировал уникальные артефакты, две капители пилястры и фрагмент плиты алтарной преграды из проконнесского мрамора. К несчастью, по сообщению ученого, эти резные детали были утрачены в ходе Великой Отечественной войны [3, с. 158-160]. Благодаря подробному описанию этих артефактов, сделанному А.С. Башкировым, и опубликованным исследователем черно-белым фотографиям мы можем составить некоторое представление о том, как они выглядели.

Капитель пилястры из проконнесского мрамора № 1 (см. рис. 3, 1) была трехсторонней «с абакой, уступчатогранной и усеченными углами, с основным и округло-котловидным (с 3-х сторон) тамбуром (барабаном), орнаментированным с лицевой широкой и с боковых сторон» [3, с. 158]. Размеры капители: высота - 0,79 м, диаметр нижней постели 0,64 м, длина верхней постели - абаки по лицевой стороне $-0,75$ м и ширина этой постели 0,62 м. Описание этой капители приводим по А.С. Башкирову: «На лицевой стороне, на слегка горизонтально-закругленной поверхности, в низком рельефе изображена двойная розетка или, точнее, 2 розетки, - одна - малая на другой - большой; малая розетка 8 -лепестковая с округло-ложкообразными углублениями лепестков, большая, служащая фоном малой, с лепестками, развивающимися вправо от вращения розетки.

Под углами абаки, на округлой поверхности тамбура, в том же низком рельефе даны в четыре шнура спирали, у которых четыре конца шнуров опущены книзу, а противополож- 

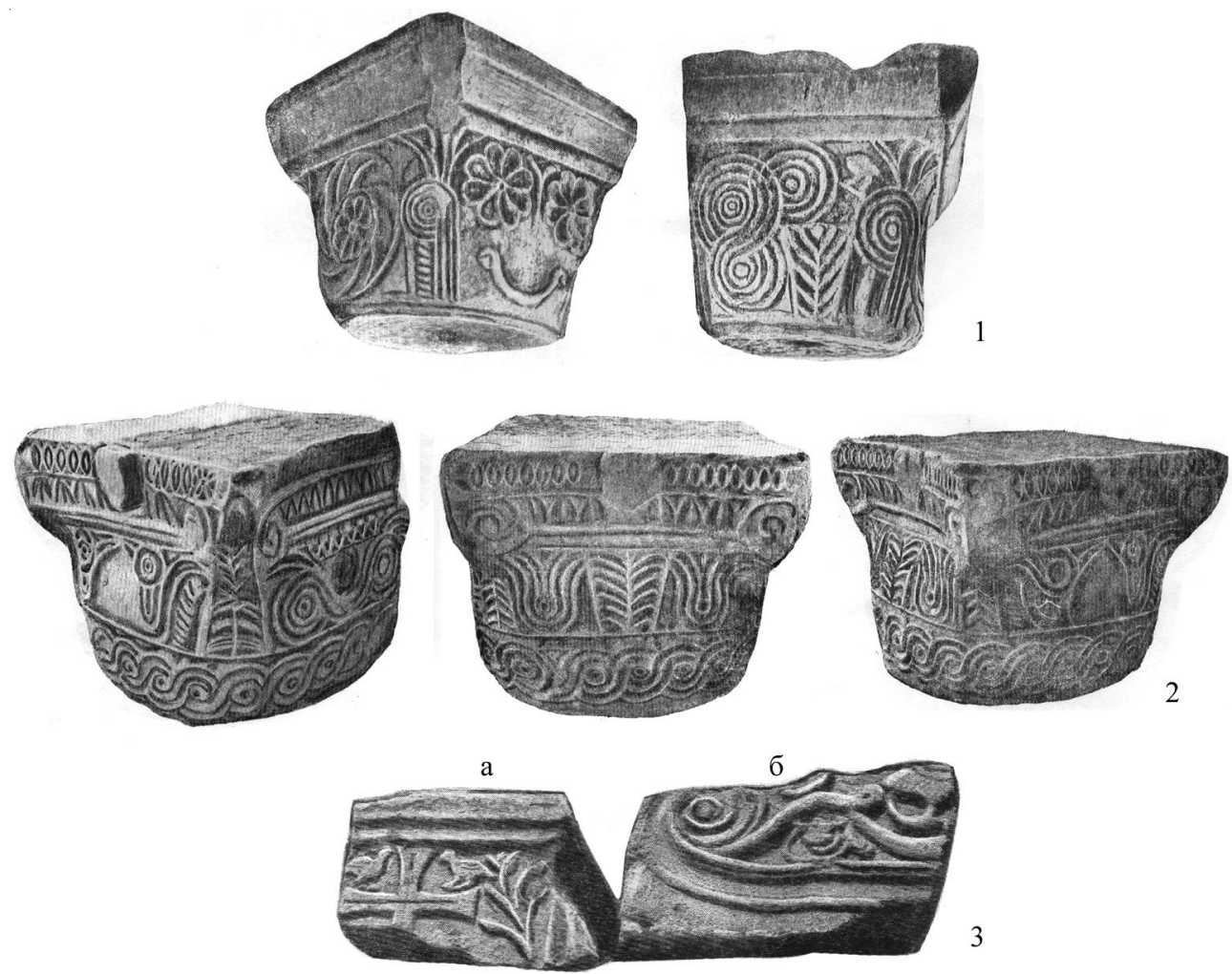

Рис. 3. Рельефы, осмотренные в Тамани А.С. Башкировым в 1926 г.

Fig. 3. Reliefs observed by A.S. Bashkirov in the Taman settlement in 1926

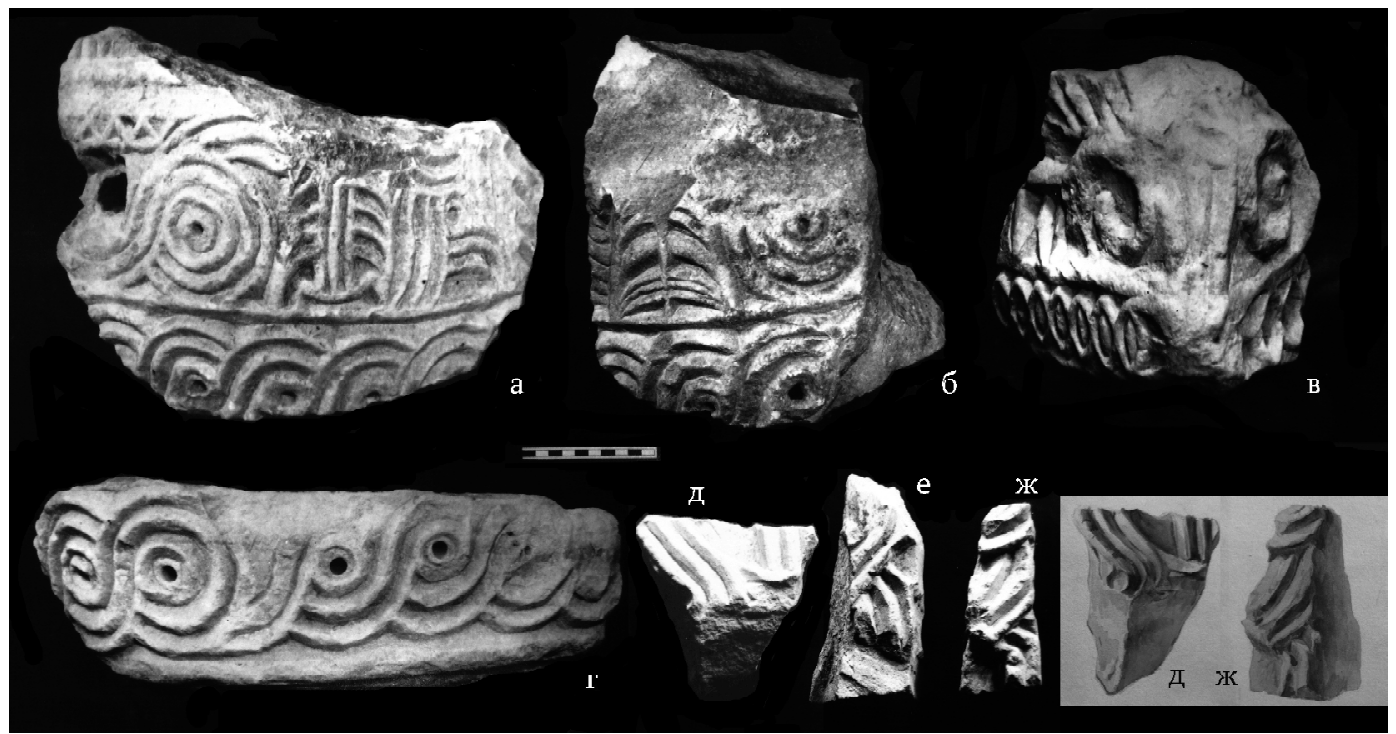

Рис. 4. Рельефы из раскопок в Тамани Б.А. Рыбакова 1953-1954 гг.

Fig. 4. Reliefs from excavations in the Taman settlement by B.A. Rybakov, 1953-1954

ные верхние концы поднимаются к углам абаки на 6 концов; под изображением спирали, как бы подчеркивая углы капители, даны витые столбики.

Правая боковая сторона тамбура капители имеет изображение двух 8-лепестковых розеток, однотипных с малой розеткой на лицевой стороне. Они размещены по сторонам тонкого стволика дерева, разветвляющегося на 2 стороны, а под всей этой 3-частной композицией изображена висящей ручка (или дужка) от котла. 
Левая боковая сторона тамбура капители сохранила изображение 2 спиралей (из 4) шнуров, переплетенных в «восьмерку», причем верхняя часть этой сложной спиралевидной “восьмерки” еще пересекается по каждому шнуру розеткой из 4 концентрических кругов. Под этой розеткой, в той же технике резьбы, помещено “деревцо” (стволик и 10 веток - по 5 веток по сторонам). Между розеткой из 4 концентрических кругов и угловой спиралью изображена в силуэтном рельефе птица» [3, с. 158-159].

Похожая по стилю и по материалу капитель пилястры № 2 (см. рис. 3, 2) представляла из себя монолитный кубовидный блок [3, c. 159]. К сожалению, ее точные размеры в отчете и публикации не указаны. Зато имеется подробнейшее описание рельефной резьбы этого артефакта. «Капитель пилястры трехсторонняя с сегментовидно-вогнутыми сторонами абаки, сходящимися на углах декорированных в резьбе имитацией ионийских волют. Между “волютами”, по лицевым сторонам в два пояса дана резная декорация, - в верхнем поясе имитируется фриз “жемчужника" в виде остроугольных, поставленных вертикально овалов, и в нижнем поясе имитируются части листьев; в центре сегментовидных сторон абаки, на высоко-рельефном полуовале изображены простые человекообразные личины (уцелела личина только на лицевой стороне).

Тамбур капители с 3 сторон покрыт в низком рельефе орнаментом в 2 полосы: нижняя, более узкая, представляет единый непрерывный фриз витого жгута из 3 шнуров с круглым “глазком" в центре; верхняя, широкая полоса с каждой стороны имеет свой орнаментальный мотив: с лицевой стороны в центре (сбито позднее) было какое-то изображение в рамке, в виде “киотца", образованного геометризированными растительными разводами, среди которых даны в двух рельефных обрамлениях “глазки”. Здесь, на лицевой стороне, возможно, была какая-то монограмма. На правой стороне тамбура капители, между волютообразными в 4 шнура спиралями, было какое-то изображение, кому-то впоследствии не понравившееся, нарочно сбитое... На левой стороне тамбура изображено многоветвистое (по 7 ветвей в сторону от ствола), засушенное до схемы “деревцо”, а по сторонам его в той же технике мелкой резьбы - имитация пальметок из акантовых (?) листьев. Между лицевой и боковой композициями, под волютообразными углами абаки даны изображения деревьев с ветками, опущенными книзу» $[3$, с. $159-160]$.

Интересно, что, по наблюдению А.С. Башкирова, вышеописанная резьба была нанесена на тело капители позднее ее изготовления, так как на ее верхней постели была видна надпись (две поврежденные строки на древнегреческом), которая по эпиграфическим признакам была отнесена к III в. [7, с. 639-640, № 1101; 10, с. 174-175]. Вероятно, как замечает А.С. Башкиров, этот блок во вторичном использовании был обработан под средневековую капитель пилястры, а первоначально служил пьедесталом скульптуры [3, с. 160].

Рассуждая о датировке капителей, А.С. Башкиров вначале относит капитель № 1 ко времени от VIII-IX вв. до XII в. [1, с. 39, pис. 7]. Затем он отмечает уникальность обеих капителей с точки зрения оригинальности представленных орнаментов и техники обработки, не имеющих ничего общего с византийскими орнаментальными сюжетами. Исследователь видит связь этих сюжетов с древнерусской деревянной резьбой и считает обе капители выполненными на территории «полусказочного удельного Тмутараканского княжества» [3, с. 162]. Со многими из этих утверждений А.С. Башкирова можно согласиться. Действительно, иконографически близких аналогий представленным капителям выявить не удалось. Однако присутствие в их декоративной резьбе некоторых элементов (восьмилепестковых розеток, схематически изображенных горизонтальной штриховкой веток дерева, и окаймляющего основной орнамент витого жгута из трех шнуров с «глазком» в центре) позволяет сблизить обе капители с декоративной резьбой по известняку из церкви Скрипу в Беотии (873-74 гг.) [20, pl. XL, 2, 3], церкви Св. Георгия Фивейского в Беотии (871 г.) [20, pl. XLIII, 2], мраморной орнаментальной плитой из Сард (IX-X вв.) [20, pl. XLIV, 2] и с известняковой капителью из Преслава (X в.) [20, pl. XLV, 1]. Некоторые типы орнамента, представленные на капители, встречаются и в средневековой пластике Абхазии. Так, витой жгут, составленный из 
двух или трех шнуров с «глазком», украшает и алтарную преграду из Анухвы (XI в.) [23, pl. $119, b-d]$. Многочисленны также аналогии по различным элементам декора среди малоазийских средневизантийских капителей [19, S. 179-180, 182-183, 195, 198, 208, 214, Taf. 1, $5 ; 2,7 ; 5,17,19 ; 6,24 ; 7,31 ; 25,138,140 ; 30$, 166; 45, 248; 53, 297].

Также упомянут фрагмент капители из проконнесского мрамора (фото не приводится), представляющий собой «прямоугольный по верхней постели импост с рельефными крестами на узких лицевых скошенных сторонах и нижнюю наклонную надколонную часть с плоско-резными волютами на узких лицевых сторонах. Размер капители: верхняя постель длина - 0,82 м, - ширина 0,53 м, диаметр нижней постели - 0,42 м, высота всей капители 0,52 м» [3, с. 160].

А.С. Башкировым также был обнаружен фрагмент алтарной преграды из проконнесского мрамора (см. рис. 3, 3a). Его размеры: наибольшая длина $-0,81$ м, ширина $-0,48$ м, толщина - 0,09 м [3, с. 160]. На лицевой стороне плиты имелось изображение в низком рельефе верхней части креста с расширяющимися к концам перекладинами и птицами по одной на концах поперечины креста. Вправо от этой композиции была помещена виноградная ветвь [3, c. 160, рис. 60]. Полная аналогия этому фрагменту выставлена в экспозиции Краснодарского историко-археологического музея (не опубликована). Плоский характер резьбы, а также техника выполнения птиц (схематичный силуэт) и ветви растения позволяют сопоставить этот артефакт с памятниками византийской архитектурной резьбы IX-X вв. [20, pl. XL, 1; XLII, 7; XLIII, 3, 4; XLIV, 3; XLV, 3].

Еще один объект - фрагмент архитектурной декорации (см. рис. 3, 3б), описание которого отсутствует (античная?).

Фрагменты рельефов, опубликованных Б.А. Рыбаковым, очень похожи по стилю и орнаменту на вышеописанные капители № 1 и 2. Скорее всего, они происходили из одного архитектурно-художественного ансамбля.

Основой орнаментального рисунка этих семи фрагментов (см. рис. 4) является мотив переплетающихся кругов небольшого диаметра, выполненных лентой плетения в три полосы. Центр каждого круга обозначен глубоко высверленным углублением. По наблюдению А. Грабара, орнаменты «плетенки» такого типа не встречаются на рельефах ранневизантийского периода [20, p. 92]. Р. Шмерлинг также относит появление этих орнаментов в архитектурной декорации ко времени не ранее начала X в. [16, с. 109]. Интересно, что по характеру орнамента одному из фрагментов (см. рис. 4,2$)$ полностью соответствует фрагмент эпистиля, балки архитрава, неизвестного происхождения из Херсонеса [18, nr 698/973, s. 313, tab. 220]. По непонятным причинам издатели каталога датируют этот рельеф из Херсонеса VI веком. Как известно, в IX-XI вв. геометрические орнаменты, составленные из ленты плетения в две и три полосы, получают широкое распространение на территории всей Византийской империи (Малая Азия, центральная Греция и др.) и в регионах, подверженных ее непосредственному культурному влиянию (Закавказье, Киевская Русь, Болгария). Они встречаются по преимуществу в архитектурной пластике. Многочисленные аналогии рассматриваемой группе рельефов подтверждают это наблюдение [21, pl. IV, $b$; VII, $a$; VIII, $c$; X, $a-c$; XXIV, $a-c$; LVII, $b$; LXXVI, $a$ и др.].

Таким образом, средневековые рельефы Таманского городища можно разделить на две хронологические группы. К первой, конца VVI в., относятся все четыре капители и фрагмент плиты с ангелом. Их присутствие подтверждает гипотезу о том, что где-то здесь находилась церковная постройка ранневизантийского периода.

Ко второй, IX-XI вв., принадлежат утерянные рельефы, запечатленные на чернобелых фотографиях из отчетов А.С. Башкирова и Б.А. Рыбакова. Цель экспедиции Б.А. Рыбакова состояла в поисках материальных остатков церкви св. Богородицы в Тмутаракани, построенной, согласно указанию «Повести временных лет», князем Мстиславом Владимировичем в 1022 г. [8, с. 377-389, рис. 1-15]. Работы экспедиции завершились обнаружением византийского храма (тип вписанного креста на четырех столбах или колоннах), построенного в X-XI вв. и просуществовавшего до XVIII в. [15, с. 37-38], что косвенно подтверждает приведенную для второй группы датировку. Аналогии и дата строительства искомой церкви позволяют, как ка- 


\section{ИСТОРИЯ, КУЛЬТУРА, ПРАВО В ВИЗАНТИЙСКИХ ПРОВИНЦИЯХ}

жется, сузить рамки предложенного в качестве датировки периода, сместив акцент в пользу XI века.

Фрагменты архитектурной резьбы с Таманского городища обоих периодов демонстрируют тесную связь с византийской художественной традицией и являются ее непосредственным отражением в Причерноморье.

\section{ПРИМЕЧАНИЯ}

${ }^{1}$ Исследование выполнено при финансовой поддержке РГНФ в рамках научного проекта № 1524-12001 (a/м) «Архитектурная пластика абхазского царства 8-11 вв.».

2 Предварительные результаты этого исследования опубликованы в виде тезисов: [5, с. 78-81].

3 Авторы сердечно благодарят главного хранителя Таманского археологического музея Э.Р. Устаеву за предоставленную информацию, касающуюся технических характеристик артефактов и их инвентарных номеров.

\section{СПИСОК ЛИТЕРАТУРЫ}

1. Башкиров, А. С. Археологическое обследование Таманского полуострова летом 1926 года / А. С. Башкиров // Труды этнографо-археологического музея 1-го МГУ. - М. : 1-й Моск. гос. ун-т, 1927. - C. $26-40$.

2. Башкиров, А. С. Отчет об историко-археологических изысканиях на Таманском полуострове летом 1948 года / А. С. Башкиров // Архив ИА РАН. - Ф-1. - Р-1. - № 249. - 94 л.

3. Башкиров, А. С. Отчет об историко-археологических изысканиях на Таманском полуострове летом 1948 г. / А. С. Башкиров // Ученые записки Московского городского педагогического института. - 1950. - Т. 13, вып. 2. - С. 133-176.

4. Брунов, Н. И. Памятник ранневизантийской архитектуры в Керчи / Н. И. Брунов // Византийский временник. - 1927. - Т. 25. - С. 87-106.

5. Ендольцева, Е. Ю. Лапидарная коллекция Таманского городища: варианты идентификации средневековых рельефов / Е. Ю. Ендольцева, В. Н. Чхаидзе // Империя ромеев во времени и пространстве: центр и периферия : тез. докл. ХХІ Всерос. науч. сес. византинистов (Белгород, 20-23 апр. 2016 г.). - Москва ; Белгород : Эпицентр, 2016. - С. 78-81.

6. Коровина, А. К. Гермонасса. Античный город на Таманском полуострове / А. К. Коровина. М. : ГМИИ им. А.С. Пушкина, 2002. - 156 с.

7. Корпус Боспорских надписей / отв. ред. В. В. Струве. - М. ; Л. : Наука, 1950. - 952 с.
8. Макарова, Т. И. Церковь Св. Богородицы в Тмутаракани / Т. И. Макарова // Материалы по археологии, истории и этнографии Таврии. - 2005. T. XI. - C. 377-405.

9. Новиков, П. В. Мраморные колонны, обнаруженные П.А. Дюбрюксом в нач. XIX века на северо-западной оконечности Таманского полуострова: к вопросу о дальнейшей судьбе и современном местонахождении / П. В. Новиков // «IV Анфимовские чтения» по археологии Западного Кавказа. Западный Кавказ в контексте международных отношений в древности и средневековье. - Краснодар : КГИАМЗ им. Е.Д. Фелицына, 2014. - С. 153-167.

10. Розанова, Н. П. Неизданные надписи Таманского музея / Н. П. Розанова // Вестник древней истории. - 1947. - № 2. - С. 174-175.

11. Рыбаков, Б. А. Отчет о работах Таманской археологической экспедиции на Таманском городище и в его окрестностях (1952-1953 гг.) / Б. А. Рыбаков // Архив ИА РАН. - Ф-1. - Р-1. - № 918-919. - 287 л.

12. Рыбаков, Б. А. Отчет Таманской археологический экспедиции за 1954 г. / Б. А. Рыбаков // Архив ИА РАН. - Ф-1. - Р-1. - № 1051-1052. - 148 л.

13. Хрушкова, Л. Г. Раннехристианские памятники Восточного Причерноморья (IV-VII вв.) / Л. Г. Хрушкова. - М. : Наука, 2002. - 500 с.

14. Чхаидзе, В. Н. Средневековый храм на Таманском городище и его архитектурный контекст / В. Н. Чхаидзе, А. Ю. Виноградов, Д. Д. Елшин // Монументальное зодчество Древней Руси и Восточной Европы эпохи средневековья. Труды Государственного Эрмитажа. - СПб., 2016. (в печати).

15. Чхаидзе, В. Н. Христианский храм в Тамани в X-XVIII вв. / В. Н. Чхаидзе// Великая Схизма. Религии мира до и после разделения церквей : тез. докл. и сообщ. XVI Междунар. конф. по истории религии и религиоведению. - Севастополь : [б. и.], 2014. - C. 37-38.

16. Шмерлинг, Р. О. Малые формы в архитектуре средневековой Грузии / Р. О. Шмерлинг. - Тбилиси : Изд-во АН Груз. ССР, 1962. - 281 с.

17. Якобсон, А. Л. Раннесредневековый Херсонес. Очерки истории материальной культуры / А. Л. Якобсон. - М. ; Л. : Наука, 1959. - 364 с. (Материалы и исследования по археологии, № 63).

18. Biernacki, A. B. Wczesnobizantyjskie elementy i detale architektoniczne chersonezu taurydzkiego/A. B. Biernacki. - Poznan : Wydawnictvo Poznańskie, 2009. - 328 s.

19. Dennert, M. Mittelbyzantinische Kapitelle. Studien zu Typologie und Chronologie / M. Dennert. Bonn : Habelt, 1997. - 232 S. - (Asia Minor Studien, Bd. 25).

20. Grabar, A. Sculptures byzantines de Constantinople (IV-X siècle) / A. Grabar. - Paris : Maisonneuve, 1963. - 139 p. 
21. Grabar, A. Sculptures byzantines du Moyen Age. II. (XI-XIV siècle ) / A. Grabar. - Paris : A. et J. Picard, 1976. -166 p.

22. Kautzsch, R. Kapitellstudien: Beiträge zu einer Geschichte des spätantiken Kapitells im Osten vom vierten bis siebenten Jahrhundert / R. Kautzsch. Berlin; Leipzig: De Gruyter, 1936. - $267 \mathrm{~S}$.

23. Khroushkova, L. Les monuments chrétiens de la côte orientale de la mer Noire. Abkhazie IV-XIV siècles / L. Khroushkova. - Turnhout : Brepols, 2006. - 340 p.

24. Tichanov-Klimenko, M. Les chapiteaux de l'église Saint-Jean-le-Précurseur a Kerć/ M. TichanovKlimenko// L'art byzantin chez les Slaves. L'ancienne Russie, les Slaves catholiques. 2 recueil. - Paris : P. Geuthner, 1932. - P. 3-24.

25. Volbach, W. F. Elfenbeinarbeiten der Spätantike und des frühen Mittelalters/W. F. Volbach. -Mainz: Verl. des römisch-germanischen Zentralmuseums, 1952.-114 S.

\section{REFERENCES}

1. Bashkirov A.S. Arkheologicheskoe obsledovanie Tamanskogo poluostrova letom 1926 goda [An Archaeological Investigation of the Taman Peninsula During the Summer of 1926]. Trudy etnografoarkheologicheskogo muzeya 1-go Moskovskogo gosudarstvennogo universiteta [Proceedings of Ethnographical-Archaeological Museum of the First Moscow State University]. Moscow, 1-y Moskovskiy gos. un-t Publ., 1927, pp. 26-40.

2. Bashkirov A.S. Otchet ob istorikoarkheologicheskikh izyskaniyakh na Tamanskom poluostrove letom 1948 goda [A Report on HistoricalArchaeological Investigation on the Taman Peninsula During the summer 1948]. Arkhiv Instituta Arkheologii Rossiyskoy Akademii Nauk [Archive of Institute of Archaeology of Russian Academy of Sciences], F-1, R-1, no. 249. 941.

3. Bashkirov A.S. Otchet ob istorikoarkheologicheskikh izyskaniyakh na Tamanskom poluostrove letom 1948 g. [A Report on HistoricalArchaeological Investigation on the Taman Peninsula During the Summer of 1948]. Uchenye zapiski Moskovskogo gorodskogo pedagogicheskogo instituta [Proceedings of Moscow City Pedagogical University], 1950, vol. 13, iss. 2, pp. 133-176.

4. Brunov N.I. Pamyatnik rannevizantiyskoy arkhitektury v Kerchi [The Monument of the Early Byzantine Architecture in Kerch]. Vizantiyskiy vremennik, 1927, vol. 25, pp. 87-106.

5. Endoltseva E.Yu., Chkhaidze V.N. Lapidarnaya kollektsiya Tamanskogo gorodishcha: varianty identifikatsii srednevekovykh relyefov [The Lapidary Collection of the Taman Settlement: Identification Options of Mediaeval Reliefs]. Imperiya romeev vo vremeni $i$ prostranstve: tsentr i periferiya. Tezisy dokladov XXI Vserossiyskoy nauchnoy sessii vizantinistov (Belgorod, 20-23 aprelya 2016 g.) [The Empire of the Romans in Time and Space: Centre and Periphery. Abstracts of the 21st All-Russian Scientific Session of Byzantine Scholars (Belgorod, April 20-23, 2016)]. Moscow; Belgorod, Epitsentr Publ., 2016, pp. 78-81.

6. Korovina A.K. Germonassa. Antichnyy gorod na Tamanskom poluostrove [Germonassa. An Antique City on the Taman Peninsula]. Moscow, GMII im. A.S. Pushkina Publ., 2002. 156 p.

7. Struve V.V., ed. Korpus Bosporskikh nadpisey [Corpus of Bosporan Inscriptions]. Moscow; Leningrad, Nauka Publ., 1950. 952 p.

8. Makarova T.I. Tserkov sv. Bogoroditsy v Tmutarakani [The Church of Blessed Virgin in Tmutorakan]. Materialy po arkheologii, istorii $i$ etnografii Tavrii [Materials on Archaeology, History and Ethnography of Tauria], 2005, vol. 11, pp. 377-405.

9. Novikov P.V. Mramornye kolonny, obnaruzhennye P.A. Dyubryuksom v nachale XIX veka na severo-zapadnoy okonechnosti Tamanskogo poluostrova: $\mathrm{k}$ voprosu o dalneyshey sudbe $\mathrm{i}$ sovremennom mestonakhozhdenii [Marble Columns Found by P.A. Dubrux in the Early 19 th Century at the North-Western Tip of the Taman Peninsula: on Their Further Destiny and Contemporary Location]. "IV Anfimovskie chteniya" po arkheologii Zapadnogo Kavkaza. Zapadnyy Kavkaz v kontekste mezhdunarodnykh otnosheniy $v$ drevnosti $i$ srednevekovye ["IV Anfimov Readings" on the Archaeology in the Western Caucasus. The Western Caucasus in the Context of International Relations in Antiquity and in the Middle Ages]. Krasnodar, KGIAMZ im. E.D. Felitsyna Publ., 2014, pp. 153-167.

10. Rozanova N.P. Neizdannye nadpisi Tamanskogo muzeya [Unpublished Inscriptions of the Taman Museum]. Vestnik drevney istorii, 1947, iss. 2, pp. 174-175.

11. Rybakov B.A. Otchet o rabotakh Tamanskoy arkheologicheskoy ekspeditsii na Tamanskom gorodishche i v ego okrestnostyakh (1952-1953 gg.) [The Report on the Work of the Taman Archaeological Expedition in the Taman Settlement and Its Surroundings (1952-1953)]. Arkhiv Instituta Arkheologii Rossiyskoy Akademii Nauk [Archive of Institute of Archaeology of Russian Academy of Sciences], F-1, R-1, no. 918-919. 2871.

12. Rybakov B.A. Otchet Tamanskoy arkheologicheskiy ekspeditsii za 1954 g. [The Report on the Work of the Taman Archaeological Expedition for 1954]. Arkhiv Instituta Arkheologii Rossiyskoy Akademii Nauk [Archive of Institute of Archaeology of Russian AcademyofSciences], F-1, R-1, no. 1051-1052. 1481.

13. Khrushkova L.G. Rannekhristianskie pamyatniki Vostochnogo Prichernomorya (IV-VII vv.) [Early Christian Monuments of the Eastern Black Sea 
Region (4th-7th Centuries)]. Moscow, Nauka Publ., 2002. 500 p.

14. Chkhaidze V.N., Vinogradov A.Yu., Elshin D.D. Srednevekovyy khram na Tamanskom gorodishche i ego arkhitekturnyy kontekst [A Medieval Temple on the Taman Settlement and Its Architectural Context]. Monumentalnoe zodchestvo Drevney Rusi $i$ Vostochnoy Evropy epokhi srednevekovya. Trudy Gosudarstvennogo Ermitazha [Monumental Architecture of Old Russia and the Western Europe During the Middle Ages. Proceedings of the State Hermitage Museum]. Saint Petersburg, 2016. (in print).

15. Chkhaidze V.N. Khristianskiy khram v Tamani v X-XVIII vv. [A Christian Temple in the Taman Settlement in the 10th-18th Centuries]. Velikaya Skhizma. Religii mira do i posle razdeleniya tserkvey. XVI Mezhdunarodnaya konferentsiya po istorii religii $i$ religiovedeniyu. Tezisy dokladov $i$ soobshcheniy [The Great Schism. World Religions Before and After the Church Division. Abstracts of Papers and Reports of the 16th International Conference on History of Religion and Religious Studies]. Sevastopol, 2014, pp. 37-38.

16. Shmerling R.O. Malye formy $v$ arkhitekture srednevekovoy Gruzii [Small Forms in the Architecture of Medieval Georgia]. Tbilisi, Izd-vo AN Gruz. SSR, 1962.281 p.

17. Yakobson A.L. Rannesrednevekovyy Khersones. Ocherki istorii materialnoy kultury [Early Medieval Chersonesus. Essays on History of Material Culture]. Moscow; Leningrad, Nauka Publ., 1959. 364 p. (Materials and Research on Archaeology, no. 63).

18. Biernacki A.B. Wczesnobizantyjskie elementy $i$ detale architektoniczne chersonezu taurydzkiego [Early Byzantine Elements and Architectural Details of Chersonesus Tauride]. Poznan, Wydawnictvo Poznańskie, 2009. 328 p.

19. Dennert M. Mittelbyzantinische Kapitelle. Studien zu Typologie und Chronologie [Middle Byzantine Capitals. Studies on Typology and Chronology]. Bonn, Habelt, 1997. 232 p. (Asia Minor Studien, Bd. 25).

20. Grabar A. Sculptures byzantines de Constantinople (IV-X siècle) [Byzantine Sculptures of Constantinople (4th-10th c.)]. Paris, Maisonneuve, $1963.139 \mathrm{p}$.

21. Grabar A. Sculptures byzantines du Moyen Age. II. (XI-XIV siècle) [Byzantine Sculptures of the Middle Ages (11th-14th c.)]. Paris, A. et J. Picard, 1976. $166 \mathrm{p}$.

22. Kautzsch R. Kapitellstudien: Beiträge zu einer Geschichte des spätantiken Kapitells im Osten vom vierten bis siebenten Jahrhundert [Capital Studies: Contributions to the History of the Late Capitals in the East From the 4th to the 7th Century]. Berlin; Leipzig, De Gruyter, 1936. 267 p.

23. Khroushkova L. Les monuments chrétiens de la côte orientale de la mer Noire. Abkhazie IV$X I V$ siècles [Christian Monuments of the Eastern City of the Black Sea]. Turnhout, Brepols, 2006. 340 p.

24. Tichanov-Klimenko M. Les chapiteaux de l'église Saint-Jean-le-Précurseur a Kerć. L'art byzantin chez les Slaves. L'ancienne Russie, les Slaves catholiques. 2 recueil. Paris, P. Geuthner, 1932, pp. 3-24.

25. Volbach W.F. Elfenbeinarbeiten der Spätantike und des frühen Mittelalters [Ivory Works of Late Antiquity and the Early Middle Ages]. Mainz, Verl. des römisch-germanischen Zentralmuseums, 1952. $114 \mathrm{p}$.

\section{Information About the Authors}

Ekaterina Yu. Endoltseva, Candidate of Sciences (Art History), Senior Researcher, Institute of Oriental Studies, Russian Academy of Sciences, Rozhdestvenka St., 19, 107031 Moscow, Russian Federation, ekaterina.endoltseva@gmail.com.

Viktor N. Chkhaidze, Candidate of Sciences (History), Researcher, Institute of Archaeology, Russian Academy of Sciences, Dm. Ulyanova St., 19, 117036 Moscow, Russian Federation, chkhaidze.v@yandex.ru.

\section{Информация об авторах}

Екатерина Юрьевна Ендольцева, кандидат искусствоведения, старший научный сотрудник, Институт востоковедения РАН, ул. Рождественка, 19, 107031 г. Москва, Российская Федерация, ekaterina.endoltseva@gmail.com.

Виктор Николаевич Чхаидзе, кандидат исторических наук, научный сотрудник, Институт археологии РАН, ул. Дм. Ульянова, 19, 117036 г. Москва, Российская Федерация, chkhaidze.v@yandex.ru. 